УДК: 159.923+316:37

Назаревич Вікторія

кандидат психологічних наук, доцент кафедри вікової та педагогічної психології, Рівненського державного гуманітарного університету

ORCID iD 0000-0002-0111-7070

DOI https://doi.org/10.35619/prap_rv.vi13.127

\title{
СОЦІАЛЬНЕ ВИГНАННЯ ЯК ФОРМА ОСТРАКІЗАЦІЇ В НАВЧАЛЬНОМУ СЕРЕДОВИЩІ
}

Анотація. У статті автор робить визначає особливості проходження процесу сочіального вигнання в просторі навчального процесу, та систематизувати сочіальнопсихологічні прояви відторгнення індивідів або груп. Особлива увага приділяється розгляду рівня динаміки соціокультурних змін, помітних проявів в характері статусно-рольових та морально-ціннісних установок, деформащії світогляду молодого покоління, яке в умовах соиіальної кризи найбільше піддається впливам та знеиіненням.

Стаття присвячена аналізу основних стадій психічної і фізичної реакиі індивіда на явище вигнання. Вказано на те, щуо особистість потребує належати до групи, щоб вижити. Як наслідок иього кожен індивід має підвищені когнітивні здібності, для вияву сигналів про відмову в сочіальному прийняті. Таким чином, відмова від намої групи академічної групи $\epsilon$ загрозливою ситуацією, як почуття особистої невпевненості.

Висвітленні фактичні умови проходження процесу соціального неприйняття особи в освітянському просторі, здійснено аналіз практичної сторони індивідуальних проявів особистості в ситуачії конфлікту в ї̈ академічній групі. Вказано на роль розгляду ситуація чіткого розподілу ролей: агресори, жертви, переслідувачі, та особливостей вікових поколінь суспільства. Зроблено висновки в системі вигняння як прояву остракізму в освітянському просторі, щзо навчальні установи являються середовищем остракізачіï, і даний процес здійснює вагомий вплий на успішність особистосного становлення учасників навчального проиесу.

Подальший розгляд даної проблеми вбачаємо в більш розгорнутому вивченні основних проявів вигняння в освітніх закладах, що виникають при загрозі приналежності, неоднозначності, невизначеності ситуачій $i$ відмови в стосунках; дослідженні взаємозалежності остракізації та індивідуальних прочесів проходження становлення в освітянській групі.

Ключові слова: сочіальне вигнання, остракізм, вигнанець, суспільство, сочіальний статус, поведінка, навчальне середовище.

Постановка проблеми. Феномен формування позиції учня - вигнанця активно досліджується вченими психолого-педагогічного спрямування в період останніх десятиліть. Висока динаміка соціокультурних змін помітно проявляється в характері статусно-рольових та морально-ціннісних установок, деформації світогляду молодого покоління, яке в умовах соціальної кризи найбільше піддається впливам та знеціненням. Такий перебіг проблеми спровокований ще не сформованою системою цінностей, мінливістю світогляду, та різкими змінами психоемоційних станів індивідів, що може призвести до втрати морального та психологічного клімату нації. Напружена та нестійка соціально-економічна ситуація розвитку суспільства зумовлює зростання різноманітних відхилень в особистісному розвитку і поведінці. Особливу тривогу викликає цинізм, жорстокість та девіантна поведінка, в результаті якої і виникає явище соціального вигнання.

Соціально відторгнена особистість, володіє більш низьким рівнем самооцінки і більш схильна до ризику проживання депресивних станів, та зовнішніх проявів агресії. Існуючі дослідження даної проблеми - $є$ кореляційними, але $є$ докази взаємних ефектів, що вказує на 
взаємозалежність наявності психо-соціальних проблем індивіда та його соціального неприйняття в системі освітнього середовища. Хронічна відмова однолітків може призвести до негативного циклу розвитку особистості.

Вагомий вплив на актуальність вивчення даної проблеми спричинив аналіз 25 випадків смертей школярів в період з 1995 по 2017 рік, який показав, що феномен соціального неприйняття однолітків фігурує у 92\% випадків. Документовані події відторгнення включали гостре і хронічне неприйняття, яке часто набувало форму остракізму, знущань i романтичного відторгнення. Досвід соціального відторгнення сприяв деприваційним мотивам та вчинкам, які були спровоковані наступними характеристиками виключених індивідів - депресія, поганий імпульсний контроль, психоемоційні психопатології.

\section{Аналіз останніх досліджень з проблеми.}

Соціальне вигнання розглядається як прояв інтолерантності в міжгруповій та міжособистісній взаємодії Бромлеєм, Головахою, Дубовим, Зазикіним. Адорно, Берковиц досліджували соціально-психологічні особливості проявів остракізації, Водак, Красних особливості формування у свідомості концепту «вигнанець». Williams i Govan вивчали вплив індивідуальних реакцій на остракізм, Carter-Sowell, Chen досліджували роль контекстуальних чинників, Govan- виконання вимог щодо зниження майбутнього остракізму в освітянському просторі.

Визначаючи спектр сучасних поглядів на дане соціальне явище та його прояви у вигляді тенденцій остракізації в середовищі освіти, та психоемоційних особливостях поведінки індивідів варто деталізувати деякі аспекти соціального відторгнення в освітньому середовищі.

Мета статті. Визначити головні причини, фактори та передумови соціального вигнання в навчальному середовищі. Відповідно до поставленої мети було визначено наступні завдання дослідження: здійснити теоретичний аналіз проблеми соціального вигнання в навчальному середовищі; з'ясувати основні причини феномену соціального вигнання в шкільному та підлітковому віці, як передумови остракізації освітнього простору.

Виклад основного матеріалу дослідження. Вигнання $є$ потужним і універсальним соціальним явищем у малих групах або діадах міжособистісної взаємодії. Вигнання мовчазна поведінка, $€$ поширеним, навіть у сімейній структурі існування особистості. Нерозривний зв'язок особистості з соціумом простежується на різних етапах розвитку науки. Аристотель зазначає: «Індивід - це соціальне створіння, соціокультурна природа якого $\epsilon$ головною і вагомою в його існуванні». 3 ранніх етапів розвитку людства самозбереження індивіда та наступного його відтворення в природі було проживання в об'єднанні (часто тимчасовому) 3 іншими, оскільки групова взаємодія забезпечує механізми безпеки та самозахисту індивідів (Eisenberger, 2003: 290 - 292).

Рефлексивна реакція на вигнання характеризується завчасною, негайною реакцією на дане явище. Область мозку, що провокує фізичний біль, дорсальна передня поясна кістка аналогічно активується під час короткого епізоду мінімального явища неприйняття (Eisenberger, 2003: 290 - 292).

Дослідники вважають, що механізми виявлення соціального «болю» та фізичного виявлення болю пов'язані з емоційними реакціями, що свідчать про підвищену потребу в соціальному захисті; характеризуються: тривогою, гнівом і депресією остракізованих. Сучасні наукові погляди розкривають думку, про наявність механізму соціокультурних істот, який автоматично виявляє соціальне відторгнення, та ініціює відповідні реакції для протидії соціальній ізоляції (Williams, 2001).

Рефлексивна реакція на остракізм характеризується навмисною $\mathrm{i}$ продуманою поведінкою індивіда, причиною якої $\epsilon$ групове неприйняття. Запобігання остракізму спрямована на відновлення або зміцнення соціально втрачених статусів особи, наслідком чого є міжгрупові або міжособистісні конфлікти, низький рівень самооцінки соціально відторгненого суб'єкта, що спровокований просоціальною поведінкою остракіза. Також проявляється потреба в особистісному контролі, спричинена втратою існуючої ролі, в 
наслідок якої збільшуться рівень прояву агресії і насильства стосовно учасників групи [Болотова, 2012].

Виділяють наступні види соціального неприйняття:

розваг і т.д.);

- $\quad$ вигнання (не дають проходу, обзивають, б'ють, переслідують з метою: помсти,

- $\quad$ активне неприйняття (виникає у відповідь на ініціативу, що виходить від жертви);

- пасивне неприйняття, що виникає тільки в певних ситуаціях (коли треба вибрати когось в команду, прийняти в гру, сісти за парту, діти відмовляються: «3 ним не буду!»);

- $\quad$ ігнорування (не помічають, не спілкуються з особою) (Дем’яненко, 2017: 128 134).

Вченні звертають увагу на індивідуальні прояви особистості, її поведінкові реакції, які часто є причиною соціального виключення.

Аналізуючи, вже існуючі психологічні дослідження, можна стверджувати: групу приваблює або відштовхує зовнішність однолітка. На його популярність, також впливають особистісні успіхи, рівень розвитку інтелекту, або когнітивні прояви. Важливим критерієм для соціального одобрення $€$ розвиток комунікативних навичок, на достатній рівень конформіських нахилів, що дозволить особистості дотримуватися загальноприйнятий групових поведінкових проявів (Зиновьева, 2003).

Вчені визначають чотири стадії психічної і фізичної реакці індивіда на явище вигнання.

На першій стадії виникає спонтанна фізіологічна реакція, яка є універсальною, і іiі сила не залежить від особистих характеристик особи чи ситуації.

Друга стадія характеризується зниженням рівня психологічного благополуччя. Вигнанець втрачає сенс існування і контроль того, що відбувається та спостерігається зниження рівня самооцінки і самоконтролю, виникають емоційно негативні реакції.

На третій стадії відбувається когнітивний аналіз ситуації, та факторів які вплинули на соціальне неприйняття. Будується стратегія подальших схем поведінки індивіда, для виходу с ситуації остракізації (Williams, 2001).

Четверта стадія характеризується значним впливом остракізації на поведінкові прояви особистості, виділяють наступні афективні реакції:

- відмова від будь-якої соціальної взаємодії, з метою мінімізації соціального болю;

- $\quad$ поведінка антисоціальної спрямованості: помста групі, відкрита агресія.

- поведінка просоціальної спрямованості, активне прагнення до спілкування, пошук нової соціальної підтримки (Williams, 2001).

В розгляді даної проблеми, доречним буде розгляд особливостей різних вікових поколінь X, У та Z. X-покоління ідентифікується спрямованістю на індивідуалізм, технологічну грамотність, рівноправність, самодостатність. У-покоління характеризуеться зверненням до морального устрою суспільства, відповідальності, відрізняючись - незрілістю, інфантилізованими тенденціями (Пископпель, 2002). Що обумовленно розвитком інформаційних технологій, як наслідок: прискорений темп життя та рух інформації, зниження ролі індивіда у реалізації будь-якої діяльності, безвідповідальність, що провокує проблему прагнення до відповідального стилю існування та підвищення рівня моральності в У-покоління, але невміння слідувати цим прагненням. Актуальне Z-покоління є сучасниками масового споживання. Виділяють вседоступність, мінімальний рівень особистісної відповідальності, масовість, конформіські нахили та прояви осіб, як наслідок: винекнення проблем у міжособистісних стосунках, високий рівень нарцисичних проявів (Протопов, 2007). 
Явище соціального вигнання як передумова остракізації є більш характерним серед осіб шкільного віку, і обумовлено відмінністями психолого-фізіологічних характеристик індивідів проживаючих даний віковий етап.

Соціально відкинута особа, виявляє нездатність нормативного розвитку, порушуєтья алгоритм проходження стадій особистісного становлення підлітка, механізмів самореалізації, комунікації, освоєння норм міжособистісної взаємодії. Посилюється відчуття незахищенності та загрози існування індивіда, що може бути спровокованим індивідуальним вибором, подібного стилю поведінки або соціальної ролі остракізованої особистості.

Дана гіпотеза звертає нашу увагу, на концепцію Карпмана - «Трикутник долі» («Драматичного трикутника»). Виділяється три соціальні ролі: «Рятівник», «Жертва» та «Агресор». Згідно критичного дискурсу розуміння життєвого сценарію Берна, існує три прояви осбистого «Я»- «Батько», «Дитина» та «Дорослий».

Активізація трикутника виключає «Дорослого», взаємодія відбувається лише на рівні «Дитини» та «Батька», особистість обирає, свідомо чи підсвідомо, соціальну роль і відповідно до цього проявляє емоційні реакції на перебуває в відповідних психоємоційних станах. Обрана роль може проявлятися як ситуативно і змінюватися невизначену кількість разів в певний проміжок часу, так і буду переважаючою в поведінкових проявах індивіда і проявлятися в усіх сферах діяльності особистості (Болотова, 2012). Кожна з ролей дає умовний дозвіл на вираження певних емоцій, та обирається 3 визначенною метою (отримання уваги, навіть якщо вона негативна, зняття з себе відповідальності, стабілізація самооцінки тощо). Трикутник обумовлює закріплення даних ролей між учасниками процесу остаракізації, та дає змогу переходу індивідів від однієї ролі до іншої, наприклад: «Жертва» швидко стає «Агресором», вимагаючи уваги «Рятівника», а «Рятівник» в свою чергу «Жертвою» (Протопов, 2007).

Кожна ситуація неприйняття передбачає чіткий розподіл ролей: агресори, жертви, переслідувачі - основна маса дітей, яка під впливом остракізаторів здійснюють вигнання. Агресор: один - два індивіда $\epsilon$ ініціаторами вигнання або активного неприйняття одного 3 учасників групового процесу. В основі будь-якого переслідування лежить прагнення самоствердитися, виділитися. Дуже рідко неприйняття - це результат особистої помсти (Williams, 2001).

Агресорів характеризують наступні індивідуальні прояви:

- високий рівень самооцінки і рівень домагання;

- прагнення об'єднати навколо себе однокласників, щоб відчути себе значущим, бути в центрі уваги;

- прагнення домогтися справедливості.

Переслідувач.

Обрана група осіб підподядковується наступним критеріям:

По-перше, підкорення думці більшості. Індивід не проводить власний когнітивний аналіз, того, що відбувається, він просто бере участь в груповій діяльності.

По-друге, бажання отримати групове одобрення.

По-третє, страх опинитися в ролі жертви.

По-четверте, шляхом переслідування задовільняється потреба в самоствердженні (Eisenberger, 2003: 290 - 292).

Часто - це особи, якими нехтують у різних процесах осціальної взаємодії, ображені, відкинуті старшими, неуспішні у навчанні і не викликають особливих симпатій в однолітків (Ясна, 2016).

Жертва.

За результатами психологічного аналізу, виділяють наступні психологічні особливості жертви: 1. Низький рівень самооцінки особистості, неадекватне визначення критеріїв соціалізації, претензія на високий рівень академічних успіхів: (в ході виконання тесту на визначення рівня домагання (рішення завдань різної складності за допомогою матриць Равена) часто вибирають складні завдання, а після невдачі вибирають ще більш складні завдання). 
2. У проективних тестах, «Діагностика шкільної тривожності» Прихожан, КАТ-Н, Тест тривожності: вигнані індивіди описують: сварки з однолітками, образи, неприйняття; ситуації взаємодії однолітків, які оцінюються більшістю як позитивні («грають разом, сміються»), жертви описують як негативні («лаються, сваряться») (Казаков, 2004).

3. За даними досліджень Крика, вигнанці повідомляють про більш сильні почуття самотності та схильні пояснювати свої невдачі в стосунках з однолітками за зовнішніми причинами. За результатами тесту особистісної фрустрації, остракізовані індивіди заперечують власну відповідальність, не відчувають почуття провини за те, що відбувається,володіють високим ступінем захисної агресії, спрямованої назовні, не намагаються знайти вихід із ситуації; не вміють адекватно сприймати критуку (Коваленко, 2006).

Таблиия 1.

Особистісні характеристики соціальних ролей за трикутником С. Карпмана.

\begin{tabular}{|c|c|c|}
\hline Роль & Характеристика & $\begin{array}{c}\text { Причини, за рахунок яких переймається } \\
\text { дана роль }\end{array}$ \\
\hline Агресор & $\begin{array}{l}\text { - висока самооцінка; } \\
\text { - рішучість; } \\
\text { - впевненість; } \\
\text { - здатність до } \\
\text { контролю над іншими } \\
\text { та керівництвом; } \\
\text { - вміння доносити } \\
\text { свою думку, позицію. }\end{array}$ & $\begin{array}{l}\text {-прагнення за рахунок інших } \\
\text { самоствердитися та отримати визнання } \\
\text { оточуючих; } \\
\text { - виділитися серед однолітків; } \\
\text { - девіантна поведінка як результат } \\
\text { особистої помсти; } \\
\text {-суб'єктивна неприязнь; } \\
\text {-високий рівень прагнення домогтися } \\
\text { справедливості; } \\
\text {-бажання бути в центрі уваги, відчути себе } \\
\text { значущим; }\end{array}$ \\
\hline Переслідувач & $\begin{array}{l}-\quad \text { високий рівень } \\
\text { прагнення } \\
\text { ідентифікувати себе } \\
\text { з лідером; } \\
-\quad \text { невпевненість у } \\
\text { своїх силах; } \\
-\quad \text { недостатня } \\
\quad \text { організованість }\end{array}$ & $\begin{array}{l}\text { - участь у вигнанні через нудьгу, заради } \\
\text { розваги; } \\
\text { - надія заслужити прихильність лідера; } \\
\text { - страх опинитися на місці вигнанця; } \\
\text { - брак власної енергї̈, щоб стати агресором } \\
\text { проте велике бажання бути схожим на } \\
\text { нього. }\end{array}$ \\
\hline Жертва & $\begin{aligned}- & \text { низька або надто } \\
& \text { висока самооцінка; } \\
- & \text { невміння постояти } \\
& \text { за себе, відстояти } \\
& \text { свою думку; } \\
- & \text { замкнутість та } \\
& \text { бажання } \\
& \text { відокремитися; }\end{aligned}$ & $\begin{array}{l}\text { - } \\
\text { зовнішня привабливість (дуже } \\
\text { приваблива або з помітними дефектами); } \\
\text { - } \quad \text { природнє вміння виділятися серед } \\
\text { однолітків; } \\
\text { - } \\
\text { висока успішність у навчанні. }\end{array}$ \\
\hline
\end{tabular}

Виділяють, ще одну соціальну роль, розглядаючі ситуацію конфлікту або виключення - захисники жертви. Існування захисника докорінно змінює відношення до існуючого остракіза - «переслідувачі» залишають вигнанця в спокої, конфлікт сходить нанівець на самому початку (Петросян, 2011).

Представник екзистенційно-гуманістичного напрямку І. Ялом наголошує на понятті ізоляція, як більш вагомому, ніж не прихильність. Вчений стверджує, що страх екзистенціальної ізоляції є рушійною силою багатьох міжособистісних відносин і важливою динамічною характеристикою феномена виключення. Вийти зі стану міжособистісної 
взаємодії означає зіткнутися з екзистенціальною ізоляцією, що супроводжується страхом і безсиллям. Проблема входження - ізоляції або, як ії зназивають, прихильність - сепарація основне екзистенціальне завдання розвитку (Williams, 2005).

Висновки та перспективи досліджень подальших досліджень. Теоретичний аналіз аспектів соціального вигнання як передумови прояву остракізації в освітньому просторі дозволив обгрунтувати поняття «вигнання», яке використовується для позначення мовчазної поведінки індивідів в різним ситуаціях міжособистісної і виключення індивіда групою. Аналізуючи теоретичні відомості, що висвітлюють дану проблему досліджено, що період перебування індивідів в соціальних групах (від 4 - до 22 років) - вигнання $\epsilon$ потужною стимулюючою соціального болю. Соціальне неприйняття часто $\epsilon$ наслідком рівня привабливості зовнішності особистості, його популярності, особистісних досягнень індивіда, рівень розвитку інтелекту, або зовнішні когнітивні прояви. Важливим критерієм для соціального одобрення $€$ розвиток комунікативних навичок, на достатній рівень конформіських нахилів, що дозволить особистості дотримуватися загальноприйнятий групових поведінкових проявів.

На основі узагальнення стану розробленої проблеми вказано на такі види соціального вигнання: вигнання (не дають проходу, обзивають, б'ють, переслідують з метою: помсти, розваг і т.д.); активне неприйняття (виникає у відповідь на ініціативу, що виходить від жертви); пасивне неприйняття, що виникає тільки в певних ситуаціях (коли треба вибрати когось в команду, прийняти в гру, сісти за парту, діти відмовляються: «3 ним не буду!»); ігнорування. Розкрито особливості осіб до наслідків соціальної ізоляції: це період підвищення самосвідомості, коли особистість намагається ідентифікувати себе 3 середовищем і групою. Констатований зв'язок із предумовами остракізації та соціальних ролей в ситуації немрийняття індивідв: «Рятівник», «Жертва» та «Агресор». Відповідно до транзактного аналізу, існування трьох проявів «Я»- «Батько», «Дитина» та «Дорослий»; вказано на відповідні характеристики соціальних ролей в просторі конфлікту в освітньому середовищі. Підтверджено важливість розгляду даної проблеми в контексті різних вікових поколінь X, У та Z. Х-покоління ідентифікується спрямованістю на індивідуалізм, технологічну грамотність, рівноправність, самодостатність. У-покоління характеризуеться зверненням до морального устрою суспільства, відповідальності, відрізняючись - незрілістю, інфантилізованими тенденціями. Актуальне Z-покоління $\epsilon$ сучасниками масового споживання. Виділяють вседоступність, мінімальний рівень особистісної відповідальності, масовість, конформіські нахили та прояви осіб, як наслідок: винекнення проблем у міжособистісних стосунках, високий рівень нарцисичних проявів, що забеспечує більший спектр теоретико-методологічного розкриття явища отракізму в освітньому просторі.

Здійснено аналіз теоретичних знань про проходження особистістю ситуації неприйняття, виділено стадії:

- спонтанна фізіологічна реакція, яка є універсальною, і іï сила не залежить від особистих характеристик особи чи ситуації.

- зниження рівня психологічного благополуччя, самооцінки i самоконтролю, виникають емоційно негативні реакції.

- когнітивний аналіз ситуації, та факторів які вплинули на соціальне неприйняття.

- $\quad$ вплив остракізації на поведінкові прояви особистості, виділяють наступні афективні реакції: відмова від будь-якої соціальної взаємодії, з метою мінімізації соціального болю; поведінка антисоціальної спрямованості, відкрита агресія; поведінка просоціальної спрямованості, активне прагнення до спілкування, пошук нової соціальної підтримки.

Виявлено, що вигнання в освітніх установах є одною із передумов проявів остракізму, навчальні установи являються середовищем остракізації, яких здійснює вагомий вплий на успішність особистосного становлення учасників навчального процесу. Подальший розгляд даної проблеми вбачаємо в більш розгорнутому вивченні основних проявів вигнання в освітніх закладах, що виникають при загрозі приналежності, неоднозначності, невизначеності ситуацій і відмови в стосунках; дослідженні взаємозалежності остракізації та індивідуальних процесів проходження становлення в освітянській групі. 


\section{СПИСОК ПОСИЛАНЬ}

Болотова, Е. Л. (2012). Насилие в школе: правовые последствия. Народное оброзование, 5, 245-248.

Дем'яненко, Б., Качур, Л. (2017). Психологічні проблеми майбутнього психолога та сучасні засоби їх подолання. Науковий часопис, 33, 128-134.

Зиновьева, Н. О., Михайлова, Н. Ф. (2003). Психология и психотерапия насилия. Ребенок 8 кризисной ситуации. Санкт-Петербург: Речь.

Казаков, В. (2004). Соціальний конфлікт: проблема визначення. Соціологія: теорія, методи, маркетинг, 3, 156-167.

Коваленко, А. Б, Корнєв, М. Н. (2006). Соціальна психологія. Київ.

Петросян, В. Р. (2011). Структурная организованность жизнестойкости старшеклассников, участников буллинга в образовательной среде. Психология обучения, 10, 100-109.

Пископпель, А. А. (2002). Концептуальные предпосылки организационно деятельной модели социального конфликта. Вопросы психологии, 6, 55-73.

Протопопов, А. (2007). Педагогический произвол в школе. Как его преодолеть? Народное образование, 4, 217-222.

Сперанский, А. (2004). Система социальних ролей ученического класса: (Изгои). Школьные технологии, 5, 214-217.

Ясна, І. (2016). Сучасні соціальні конфлікти: спроби концептуалізації. Філософська думка, 4, 104-117.

Eisenberger, N. I., Lieberman, M. D., \& Williams, K. D. (2003). Does rejection hurt? An fMRI study of social exclusion. Science, 302, 290-292.

Williams, K. D. (2001). Ostracism: The power of silence. New York: Guilford Press.

Williams, K. D., \& Forgas, J. P. (2005). The social outcast: Ostracism, social exclusion, rejection, and bullying. New York: Psychology Press.

\section{REFERENCES}

Bolotova, E. L. (2012). Nasilye v shkole: pravovye posledstviya [Violence at school: legal implications]. Public education, 5. 245-248. [in Russian].

Dem'yanenko, B., \& Kachur, L. (2017). Psycholohichni problemy maybutnoho psycholoha ta suchasni zasoby yikh podolannya [Psychological problems of the future psychologist and the most important misfortune]. Science Chronicle, 33, 128-134. [in Ukrainian].

Zinovieva, N. O., \& Mikhailova N. F. (2003). Psychologiya i psykhotherapiya nasiliya. Rebenok v krizisnoy situatsii [Psychology and psychotherapy of violence. A child in a crisis]. SanktPeterburh: Speech. [in Russian].

Kazakov, V. (2004). Socialnyi conflict: problema viznachenniya [Social conflict: the problem of visibility]. Sociology: theory, methods, marketing, 3, 156-167. [in Ukrainian].

Kovalenko, A. B, \& Korn€v, M. N. (2006). Socialna psycholohiya [Social psychology]. Kiev. [in Ukrainian].

Petrosyan, V. R. (2011). Strukturnaya organizovannost zhiznestoykosti starsheklassniov, uchastnikov bullinga $\mathrm{v}$ obrazjvatelnoy srede [Structural organization of the resilience of high school students, bullying participants in the educational environment]. Training Psychology, 10, 100-109. [in Russian].

Piskoppel, A. A. (2002). Kontsceptualnie predposilki organizatscionno deyatelnoy modeli sotscialnogo konflikta [Conceptual background of an organizationally active model of social conflict]. Psychological Issues, 6, 55-73. [in Russian].

Protopopov, A. (2007). Pedagogicheskiy proizvol v shkole. Kak ego preodolet ? [Pedagogical arbitrariness at school. How to overcome it?]. Public education, 4, 217-222. [in Russian].

Speransky, A. (2004). Sistema socialnykh roley uchenicheskogo klassa: Izgoi [The system of social roles of the student class: Outcasts]. School technology, 5, 214-217. [in Ukrainian].

Yasna, I. (2016). Suchasni sotscialni konflikti: sprobi kontsceptualizatscii [Social Conflicts: Try Conceptualization]. Philosophical thought, 4, 104-117. [in Ukrainian]. 
Eisenberger, N. I., Lieberman, M. D., \& Williams, K. D. (2003). Does rejection hurt? An fMRI study of social exclusion. Science, 302, 290-292. [in English].

Williams, K. D. (2001). Ostracism: The power of silence. New York: Guilford Press. [in English]. Williams, K. D., \& Forgas, J. P. (2005). The social outcast: Ostracism, social exclusion, rejection, and bullying. New York: Psychology Press. [in English].

\title{
SOCIAL EXILE AS A FORM OF EXTRACTION IN THE EDUCATIONAL ENVIRONMENT
}

\author{
Victoria Nazarevich, \\ PhD (Psychology), \\ Associate of the head of the \\ Department of Lifespan \& Pedagogical Psychology \\ Rivne State University of the Humanities \\ ORCID iD 0000-0002-0111-7070 \\ DOI https://doi.org/10.35619/prap_rv.vi13.127
}

\begin{abstract}
The author of the article made a research of recognizing the particularities of going through the process of social cognition in the space of the initial process, and that of systematizing social and psychological manifestation of indivisibility of an individual group. There is a special respect for looking at the high level of dynamics of the social and cultural sights, the significant manifestations in the character of the status-role and moral attitudes, the deformation of the young generation, as well as in social wisdom.

The article is dedicated to the important analysis of the main stages of the psychological and physical reaction of the individual to the sign of exile. It is pointed out that those who need special care will need to lie down to a group, so that they can see. As a result, we've got a signal about a social message for people who'd like. Thus, the presentation of our group of the academic group $\epsilon$ a threatening situation, as if considering a special non-indulgence. In the article the author analyzed ependent on the actual facts, go through the process of social non-acceptance of individuals in the open space, analysis of the practical side of the individual manifestations of the situation in the academic group.

The author highlighted the role of looking at the situation of clearly distinguished such as: aggressors, sacrifices, interrogations, and special features of great generations of suspension.

The furthest attention to the given problem and to the widening of the unfolded investigatiton main manifestations of higher mortgages, to be guilty in case of threat of belonging, ambiguity, uninterestedness and negligence in the slots. Prerequisites for mutual ostracization and individual processes, the process of becoming established in the development group.

Key words: social exile, ostracism, ejection, suspension, social status, behavior, first middle ground.
\end{abstract}

